\title{
Strategi Pemasaran Digital Peternakan Pada Produk Susu Perah Sapi (Studi Kasus : CV Langgeng Tani Makmur)
}

\author{
${ }^{1}$ Adhi Widyakto, ${ }^{2}$ Endang Tri Widyarti, \\ ${ }^{1}$ S1 Manajemen FE, Universitas Semarang,Semarang,Indonesia \\ ${ }^{2}$ S1 Manajemen FEB, Universitas Diponegoro,Semarang,Indonesia
}

\section{INFO ARTIKEL}

Proses Artikel

Dikirim :

Diterima:

Dipublikasikan:

\begin{abstract}
ABSTRAK (TNR 10)
Pemasaran offline dalam produk peternak susu sapi perah telah memakan banyak biaya. Tingginya biaya pemasaran berdampak pada harga jual yang kurang kompetitif. Pemasaran digital menjadi solusi yang tepat dalam permasalahan ini. Tujuan dari penelitian ini buat analisis strategi pemasaran digital paling tepat untuk perusahaan. Metode yang dipakai adalah analisis sostacs. Hasil penelitian menyebutkan bahwa perusahaan mengkombinasikan pemasaran offline dan online. Media yang digunakan adalah marketplace dan sosial media. Marketplace peternak susu sapi perah dan media sosial facebook difokuskan untuk memberi informasi yang lengkap terkait produk dan promosi yang massif untuk meningkatkan penjualan. Sementara media sosial whatsapp lebih difokuskan untuk membangun relasi dan kedekatan personal untuk menciptakan loyalitas pelanggan
\end{abstract}

\section{Kata Kunci :}

Produk Susu Sapi Perah, Pemasaran Digital, Manajemen Pemasaran.

\section{PENDAHULUAN}

$\mathrm{Cv}$ Langgeng Tani Makmur adalah sebuah badan usaha bergerak dibidang pengolahan dan perdagangan produk Susu Sapi Perah partai sedang. Produk utama yang diolah dan diperdagangkan adalah Susu dan Yogurt. Dalam menjalankan promosinya, bagian pemasaran CV Langgeng Tani Makmur menerapkan teknik personal selling dan direct marketing. Dharmmesta dan Handoko (2011) menjelaskan bahwa personal selling atau penjualan personal, merupakan penjabaran atas persepsi yang dikeluarkan diri individu oleh para pegawai perusahaan untuk mendukung terciptatanya kesukseskan kegiatan bisnis dan membangun hubungan dengan pelanggan. Bagian pemasaran CV Langgeng Tani Makmur, yang berlokasi di wilayah strategis, mempresentasikan produk dan jasa yang dimilikinya secara persuasif dan agresif kepada semua calon pelanggan yang datang. Untuk membangun hubungan Kerjasama jangka Panjang, bagian pemasaran Cv Langgeng Tani Makmur selalu meminta kontak pelanggan untuk kemudahan komunikasi. Direct marketing atau pemasaran langsung, suatu metode penjualan dengan cara 
berkomunikasi secara langsung dan memperoleh tanggapan langsung dari konsumen, di pemasaran secara langsung ini tanpa memerlukan perantara pemasaran pada bargaining process (transaksi tawar-menawar) sebuah produk. Bagian pemasaran CV Langgeng Tani Makmur melakukan direct marketing dengan menghubungi semua calon pelanggan potensial melalui telepon untuk mendapatkan tanggapan langsung. Jika tanggapan yang diperoleh adalah positif maka sampel produk akan dikirim ke alamat calon pelanggan. Teknik promosi ini ditinjau dari perspektif keuangan membutuhkan biaya yang tinggi yang kemudian berdampak pada harga jual produk yang tidak kompetitif.

(Wardhana, 2015) menyatakan bahwa salah satu keunggulan pemasaran digital adalah biaya yang digunakan jauh lebih rendah daripada pemasaran konvensional. Rendahnya biaya pemasaran digital ini diharapkan dapat berpengaruh pada harga jual yang kompetitif guna menarik perhatian lebih banyak pelanggan. Selain itu, pemasaran digital memanfaatkan teknologi internet yang membuat nyaman konsumen dilihat dari segi kemudahan akses dan kepraktisan. Pelanggan bisa membeli produk kapan dan dimana pun cukup memakai gawai. Transaksi pembayaran juga semakin mudah dengan memanfaatkan fasilitas mobile banking, Shoopee Pay, electronic money (e-money). Mokhtar (2015) menambahkan kalau pemasaran dengan Internet memperluas jangkauan pasar, serta menghemat biaya Kegiatan pemasaran produk dapat digunakan sebagai wujud meningkatkan hubungan yang baik diantara perusahaan sama konsumen. Dengan menerapkan internet marketing, perusahaan dapat menghemat biaya promosi. Perusahaan yang memanfaatkan media sosial untuk memasarkan produk hanya memerlukan kuota, yang ditinjau dari segi biaya sangat terjangkau bila dibandingkan dengan pulsa telepon dan sms. Perusahaan lain yang memiliki anggaran khusus untuk periklanan digital dapat memanfaatkan advertising tools seperti google adsense, facebook adsense, instagram adsense, youtube adsense, twitter adsense yang ditinjau dari sisi biaya, meskipun lebih tinggi dari biaya pemasaran melalui media sosial saja, tetapi dapat dijangkau oleh masyarakat luas jika dibandingkan dengan biaya pemasaran konvensional (Febriyantoro \& Arisandi, 2018). Harga yang tidak kompetitif dapat mempengaruhi keputusan pembelian konsumen yang secara kolektif berdampak pada volume penjualan (Amilia, 2017). Dengan pertimbangan tersebut, bagian pemasaran CV Langgeng Tani Makmur akan menerapkan strategi pemasaran digital.

\section{Rumusan Masalah}

Permasalahan mendasar yang dialami perusahaan adalah tidak kompetitifnya harga produk sebagai akibat dari tingginya biaya pemasaran offline. Oleh karenanya, perusahaan berinisiatif untuk menerapkan pemasaran digital. Produk peternakan sapi memiliki ciri kas yang berbeda diantara beberapa produk di sektor industri lainnya. Seperti halnya pada ciri khas produk yang punya masa batas waktu dan daya tahan produk yang terbatas (Utami \& Firdaus, 2018) Maka itu perlu analisis dengan matang rencana penjualan yang mau dipakai. Penelitian ini bermaksud guna menganalisis seperti apa strategi pemasaran digital yang tepat untuk diterapkan pada produk peternakan. Untuk mempermudah analisis, maka dapat menjadi pertanyaan penelitian sebagai berikut:

1. Bagaimana analisis 4P untuk Produk Peternakan?

2. Bagaimana Analisis STP untuk Produk Peternakan?

3. Bagaimana analisis SOSTACS untuk produk Peternakan? 


\section{KAJIAN PUSTAKA}

\section{Promotion Mix}

(Kotler, Philip,. Keller, 2016) menjelaskan bahwa bauran promosi atau sangat diketahui umum promotion mix terbagi atas iklan, promo pemasaran, acara dan pengalaman, hubungan masyarakat dan publisitas, penjualan langsung dan database, penjualan online dan media sosial, pemasaran mobile dan personal selling. Advertising (Periklanan) suatu pesan untuk meyakinkan orang lain lewat media massa yang punya maksud guna mengenalkan produk ataupun jasa yang dijual oleh Perusahaan.

Sales promotion (Promosi Penjualan), kegiatan yang dilakukan buat mengkomunikasikan sesuatu barang atau jasa kepada konsumen buat secepatnya melakukan Tindakan. Sehingga dapat menaikkan angka penjualan dari setiap barang dan jasa yang diciptakan sama perusahaan punya maksud mempengaruhi konsumen buat membeli barang atau jasa dengan jalan mempengaruhi sisi pikiran yang masuk akal dan rasional.

Events and experiences (Acara dan pengalaman), suatu bila perusahaan mensponsori kegiatan dan programguna interaksi merk secara khusus dan dari event and experiences ini bisa meningkatkan loyalitas konsumen, guna dikenalkan keunggulan suatu barang, membikin paket pemasaran, mengenalkan barang ke orang lain, menambah user website, mendapatkan masukan dari konsumen serta mendekatkan perusahaan dengan target.

Public Relation and publicity public Relation adalah rencana yang direncanakan guna mengenalkan atau melindungi citra perusahaan atau produk-produknya. Publisitas adalah informasi itu memiliki nilai berita dengan tidak membayar.

Direct Marketing and database (Penjualan langsung) yaitu gimana kalian menciptakan suatu tatapan langsung dengan pelanggan kalian dan pelanggan potensial kalian sewaktu melaksanakan kampanye iklan layanan atau produk. Database marketing adalah strategi yang melibatkan pengumpulan data konsumen dengan tujuan untuk memahami kebutuhan mereka dan memberikan solusi melalui komunikasi yang dipersonalisasi.

Online and social media marketing adalah suatu wujud penjualan digital yang memakai media sosial dan situs web guna mengenalkan produk atau jasa yang anda pasarkan dan pelanggan produk atau jasa yang kalian jual merupakan pengguna sosial media seperti instagram, facebook, dan youtube.

Mobile marketing (Pemasaran mobile), yaitu sistem pemasaran yang mengandalkan penayangan via mobile atau yang di kenal dengan smartphone dengan menggunakan aplikasi khusus. guna mencapai target pembeli di smartphone, tablet, dan perangkat seluler lainnya, lewat situs web, email, SMS dan MMS, media sosial, dan aplikasi.

Personal Selling (Penjualan personal), yaitu bertemunya penjual dan calon pembeli dalam sebuah komunikasi yang bertujuan untuk memperkenalkan sebuah produk dan mendapatkan interest pembeli. Strategi ini dilakukan dengan cara menjalin komunikasi dengan pembeli secara 
personal. Dengan strategi ini diharapkan konsumen lebih mudah mengetahui eksistensi sebuah produk sementara dari sisi perusahaan, maka perusahaan dapat dengan mudah mengetahui siapa saja konsumennya.

Segmenting Targeting Positioning

(Kotler, Philip,. Keller, 2016) menyatakan bahwa ada tiga komponen pada kebijakan penjualan yaitu segmenting, targeting, dan positioning.

1. Segmenting yaitu sistem memecah pasar menjelma bagian-bagian pembeli potensial, di mana setiap bagian mempunyai sifat yang sama dan cenderung mempunyai sifat pembelian yang sama. Dan bertujuan guna mendapatkan sektor pasar yang memiliki ciri dan sifat yang sangat sejenis.

2. Targeting diartikan sebagai perbuatan mengukur animo dari berbagai bagian pasar, selanjutnya memilih bagian pasar mana yang akan kalian jadikan menjadi target pasar. Dari targeting dapat Mengantisipasi persaingan dan Akses peluang pasar lebih luas.

3. Positioning, yaitu satu perbuatan atau langkah-langkah dari produsen guna merancang representasi perusahaan dan penawaran harga dimana pembeli didalam suatu bagian tertentu memahami dan menilai apa yang diperbuat suatu bagian tertentu, memahami dan menilai apa yang diperbuat suatu perusahaan, dibandingkan sama kompetitornya.sampai terbentuk kesan tertentu dalam benak pembeli.

Internet Marketing

(Chaffey, D \& Smith, 2008) E-Marketing, internet marketing atau pemasaran secara elektronik, mewujudkan pusat dari sesuatu e- business, dengan menciptakan dan merawat ikatan bersama pelanggan lewat aktifitas secara online buat bertukar gagasan atau memahami kebutuhan pelanggan dan menaikkan harga dari suatu barang. Sehingga bisa memperlebar dan menaikkan hasil penjualan produk melalui aktivitas e-marketing yang bersumber pada media digital seperti penjualan lewat internet, promosi online memalui social media dan jenis penjualan lainnya.

\section{Jenis Pemasaran Online}

(Chaffey, D. Chadwick, F. Johnston, 2009) mengidentifikasi ada tiga jenis pemasaran online presence yakni sebagai berikut:

- Situs E- Commerce transaksional. Perusahaan manufaktur, e-retailer, atau menjalankan produk yang dipasarkan melalui situs online. Penyokong utama lewat jualan produk. Situs ini dapat menunjang agar memudahkan konsumen dalam pemilih produk. .

- Situs pembangun layanan atau lead-generation web site. Dengan adanya situs dapat memberikan informasi sejalan dan dapat membina hubungan dengan pembeli. Informasi yang diberikan tidak sembarang online, tetapi melalui website, beserta e-mail marketing. Kontribusi yang dilakukan harus diinbangi dengan melakukan penjualan offline dan menggugah respon spesifik atau lead, pada kasus e- marketing dari konsumen potensial sesui kebutuhan mereka. 
- Media sosial atau situs komunitas. Situs media sangat memudahkan hubungan berupa tanggapan, balasan, pesan, atas konten dan mengidentifikasi konten untuk kategori tertentu, misal Facebook dan Linkedln dan sebagainya. Disamping itu situs jenjaring social, interaksi social dapat dikategorikan lewat plug-in atau application programming interfaces (API).

Jenis E-commerce

Berdasarkan Laudon dan Laudon (2008:63), pengelompokkan E- Commerce dibedakan sebagai berikut:

- Business to Consumer (B2C). karakteristik yang dimiliki diantaranya bersifat terbuka, yang mana informasi ini tersebarkan ke khalayak umum dan bisa diakses dengan bebas. Pelayanan yang dipakai bersifat umum maka daripada itu bisa dipakai untuk banyak orang. contoh: sistem berbasis web

- Business to business (B2B). Mitra dagang yang terjalin hubungan diantara mereka dalam kurun waktu cukup lama dan saling memahami, mereka saling berbagi informasi. Informasi atau data dikirimkan dengan format yang telah disetujui Bersama dan dilakukan secara berulang-ulang.

- Consumer to Consumer $(\mathrm{C} 2 \mathrm{C})$. Jenis $\mathrm{C} 2 \mathrm{C}$ ini dapat didefinisikan sebagai seorang konsumen dapat menjual produk barang maupun jasa langsung kepada pembeli lain. misalnya adalah waktu ada individu yang menawarkan di classified ads (contohnya, www.classified2000.com) dan menawarkan properti tempat tinggal, mobil, dan lainnya. Mempromosikan jasa pribadi di internet serta menawarkan ilmu dan ketrampilannya sebuah contoh lain C2C.

- Peer-to-peer (P2P). Peer to peer adalah model yang umum digunakan yang mana processing dan intelligence dapat disalurkan di kedua pelaku bisnis

- Mobile Commerce (M-Commerce). System perbelanjaan elektronik serta memakai peralatan portable atau mobile semisal handphone, smartphone, PDA, notebook dan lain-lain. Pada waktu pemakai computer berganti dari satu daerah ke daerah lain, pemakai computer termaktub bisa mengadakan transaksi jual beli produk di internet dengan memakai system mcommerce.

\section{SOSTAC Analysis}

SOSTAC adalah salah satu metode analisis dalam pemasaran digital yang digunakan dalam pembuatan kerangka pada skema e-marketing yang dimunculkan oleh PR Smith. SOSTAC adalah singkatan dari Situation analysis, Objectives, Strategy, Tactics, Actions, and Control. (Chaffey, D \& Smith, 2008) menjabarkan beberapa definisi dari tahapan prosedur berikut ini:

- Situation analysis 
Adalah tahap awal dilakukannya analisis mengenai situasi yang terjadi dan situasi yang dipelajari mengenai aspek-aspek yang bisa berdampak kepada kelompok, baik kedalam maupun keluar. Dalam mempelajari situasi, kita mampu mengenali siapa diri kita, apa yang kita lakukan, dan bagaimana kita bersosialisasi serta melaksanakan perdagangan secara online. Analisis situasi meliputi analisis terhadap konsumen, SWOT, kompetitor dan lanskap kanal digital.

\section{- Objectives}

Pada tahap ini, perusahaan mempraktikkan susunan kerja pada digital marketing adalah fokus terhadap tujuan dan strategi yang akan kita susun, sehingga mencapai hasil yang diinginkan.

- Strategy

Bagaimana perusahaan mencapai objecttives yang sudah dibuat sebelumnya. Dalam menyusun strategi, harus megetahui segmen yang akan dituju dalam kegiatan pemasaran pada sebuah bisnis, strategi-strategi ini yang akan mendukung tercapainya target dan tujuan.

\section{- Tactics}

Taktik yaitu detail dari strategy dan meliputi alat khusus yang dipakai buat menggapai maksud dari pemasaran digital. Perusahaan dengan menerapkan bauran pemasaran 7P yaitu Produk, harga (price), tempat (Place), Promosi, orang-orang (People), Proses, dan kemitraan (Partnerships).

- Actions

Action yaitu detail dari tactics dan hasil praktik dari perusahaan yang tersusun menjadi kerangka kerja pada pemasaran digital yaitu mengusung agenda membuat nyata lewat sistem tindakan yang terarah.

\section{- Control}

Control merupakan tahap akhir, Control merupakan tahap akhir dimana perusahaan mempraktikkan susunan rencana kerja pada digital marketing yaitu mengontrol dan menaksir kinerja berlandas sasaran yang diterapkan oleh keseluruhan pegawai dalam perusahaan. Dengan memperhatikan strategi yang telah ditetapkan. Sehigga mendapatkan hasil yang maksial.

\section{METODE PENELITIAN}

Penelitian ini adalah penelitian kualitatif dengan studi kasus pada CV Langgeng Tani Makmur. Data yang dipakai dalam penelitian ini adalah data primer berupa wawancara terstruktur dengan bagian pemasaran objek penelitian. Objek dari penelitian ini adalah CV Langgeng Tani Makmur. Teknik pengumpulan data dilaksanakan dengan studi Pustaka. Teknik analisis data dilakukan dengan menggunakan alat analisis pemasaran 4P, STP, SOSTAC 


\section{HASIL DAN PEMBAHASAN \\ Gambaran umum perusahaan}

CV Langgeng Tani Makmur adalah usaha dagang yang bergerak dalam pengolahan dan perdagangan produk Susu Sapi Perah. CV Langgeng Tani Makmur menawarkan jasa pengolahan Susu Sapi perah sesuai dengan permintaan konsumen. Permintaan konsumen berupa grade kualitas yang disesuaikan dengan kebutuhan. Kapasitas produksi dalam satu minggu sekitar 150 Liter susu.

- $\quad$ Produk.

Produk utama yang ditawarkan perusahaan adalah susu dengan kuantitas pembelian minimal $400 \mathrm{ML}$.

- Price (Harga).

Harga produk, mengacu pada data historis, bersifat cenderung stabil. Harga produk secara general dipengaruhi oleh permintaan dan penawaran. Penetapan harga dilakukan dengan menjumlahkan harga pokok produksi dan margin keuntungan.

- Place (Saluran distribusi).

Perusahaan berlokasi strategis di jalan Semarang-Boyolali. Cv Langgeng Tani Makmur mendapatkan produknya dari pedagang yang dalam rantai pasokan berada tepat dibawahnya dan langsung dari peternak. Setelah proses pengolahan, Perusahaan mendistribusikan produk kepada pelanggan yang terdiri dari pabrik dan konsumen.

- Promosi.

Promosi yang dilakukan selama ini adalah dengan Teknik personal selling dan direct marketing. Biaya yang diperlukan diantaranya adalah pulsa telepon dan sms, bensin, jasa ekspedisi untuk pengiriman sampel. Perusahaan sedang mempertimbangkan untuk menerapkan digital marketing.

- Analisis STP.

Segmenting adalah kegiatan mengelompokkan pasar. Segmentasi produk perusahaan dilakukan berdasarkan jumlah pembelian yakni partai susu, grosir, ecer. Targeting adalah menentukan target pasar mana yang akan dipilih setelah proses segmentasi. Target yang dipilih perusahaan adalah partai besar, dengan pembelian minimal $400 \mathrm{Ml}$. Positioning adalah bagaimana perusahaan memposisikan produknya agar berbeda dari kompetitor sehingga berkesan dan diingat oleh pelanggan. Sebelum melakukan positioning, perlu diketahui dahulu bahwa kegiatan operasional perusahaan adalah melakukan pengadaan komoditas, pengolahan produk sesuai pesanan pelanggan (custom) dari segi kualitas dan kuantitas dan penjualan. Jadi value added yang melekat pada produk terletak pada jasa perusahaan dalam mengolah produk sesuai pesanan pelanggan. Dengan demikian perusahaan memposisikan dirinya sebagai perusahaan yang kompeten dan terpercaya. Berdasarkan literature review yang telah dipaparkan maka jenis pemasaran digital yang dipilih perusahaan mengacu pada Situs e-commerce transaksional. Situs e-commerce berkontribusi utama dalam pemasaran barang. Situs dapat membantu bisnis lewat cara membagi informasi pada pemakai yang lebih menentukan buat membeli barang secara offline. E-Commerce dapat diciptakan sebagai media promosi, komunikasi dan informasi serta bisa memangkas alur distribusi penjualan hasil peternakan (Apriadi \& Saputra, 2017). Berdasarkan klasifikasi situs e-commerce, perusahaan menggunakan situs e-commerce B2B. e 
commerce B2B sering juga disebut dengan marketplace. Berikut adalah daftar situs marketplace B2B yang bergerak dibidang peternakan (Finansialku, n.d.)

\section{Agromaret}

Agromaret adalah komunitas dan marketplace yang berfokus pada sektor peternakan susu dan telah beroperasi sejak tahun 2009. Agromaret bertujuan untuk mengurangi dominasi pasar bagi sekelompok orang, menciptakan peluang pasar yang seluas-luasnya bagi para peternak, menjadi sentra informasi di bidang peternakan.

\section{Tanihub}

Tanihub berdiri pada tahun 2016. TaniHub membidik 2 kriteria konsumen yaitu perorangan dan juga barang dagangan. Situasi ini dikarenakan masih ramai orang yang lebih suka membeli buah dan sayur di pasar tradisional dan supermarket daripada online.

3. Peternak

Peternak berdiri tahun 2015. Penggunan software Peternak berpusat di jasa informasi buat para peternak. Semoga bisa mendidik seluruh peternak Indonesia bisa membuat bertambah maju bersama meningkatnya informasi dan pengetahuan para peternak diseputar problematika peternak.

\section{Lima Kilo}

Lima Kilo berdiri pada Tahun 2015. Tujuan memangkas jalur distribusi hasil peternakan, di mana konsumen dan penjual langsung bertemu. Dan harapannya pendapatan peternak bisa bertambah sampai $10 \%$ dan harga jual di pembeli dapat dipangkas $10 \%$.

\section{Pantau Harga}

Pantau Harga berdiri pada tahun 2015. Pantau Harga punya maksud buat menolong pembeli mengamati harga produk pangan di daerah seputar mereka, dan berbelanja barang itu sama kualitas serta harga yang bersaing.

Dari daftar marketplace tersebut, perusahaan memilih Agromaret. Agromart dipilih dengan berbagai pertimbangan diantaranya usia, ramah user, kelengkapan fitur dan ketersediaan mobile application. Agromart merupakan pionir marketplace pertanian di Indonesia yang didirikan pada 2009 dan masih bertahan hingga tahun 2020. Artinya agromart memiliki track record dan kredibilitas yang baik. Agromart memiliki tampilan yang ramah pengguna sehingga memudahkan pengguna dalam mempelajari cara kerja dan transaksi. Agromart merupakan salah satu marketplace peternakan yang dapat diakses melalui website dan aplikasi yang dapat diunduh dari Appstore atau playstore. Hal ini menjadi nila plus dalam fleksibilitas. Kelebihan agromart yang tidak dimiliki oleh marketplace lain adalah adanya kategori system kerja yang terdiri dari penjualan, permintaan dan Kerjasama. Rentang skala jual beli yang ditawarkan oleh agromart mulai dari $400 \mathrm{ML}$ hingga ratusan liter. Perusahaan dapat menggunakan agromart sebagai sarana untuk mempromosikan produknya guna mendorong transaksi penjualan baik online maupun offline.

Untuk memungkinkan interaksi antara komunitas antara konsumen yang berbeda dan membangun relasi dengan pelanggan maka diperlukan jejaring sosial. 


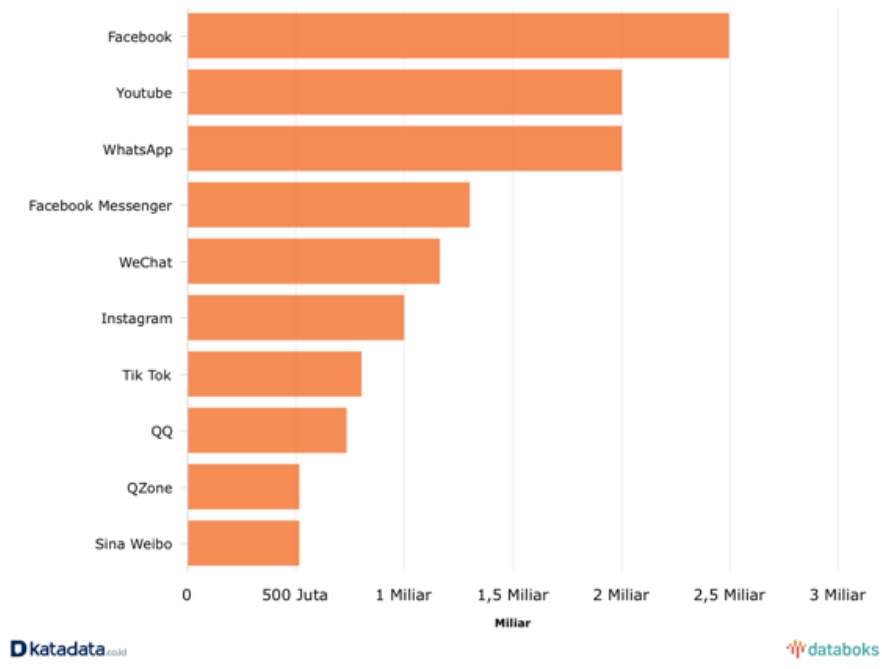

Berdasarkan data yang dilansir dari (Berita Terkini Ekonomi dan Bisnis Indonesia - Katadata, n.d.), facebook merupakan media sosial dengan pengguna terbanyak. (Muttaqin, 2012) menyatakan bahwa facebook dapat digunakan untuk mengelola hubungan pelanggan. Facebook juga menyediakan fungsi informasi yang dapat perusahaan gunakan untuk menampung detail informasi produk.

1. Facebook menyediakan fungsi informasi

Pemadaran melalui media social facebook lebih diminati oleh selurah kalangan. Dikarenakan media social facebook sudah mencakup data-data pribadi, alamat perusahaan, hobi ownernya, dll.

2. Segmentasi pasar lebih fokus

Dengan social media facebook, segementasi pemasarannya lebih luas. Dikareanakan segmentasi pemasaran dari seluruh Indonesia maupun luar negeri dapat mengakses media social facebook.

\section{Kemudahan akses}

Siapapun dapat mengakses media sosial Facebook kapanpun dan dimanapun ketika terhubung dalam jaringan internet dengan menggunakan gawai.

4. Kemudahan komunikasi

Fitur komunikasi yang disediakan oleh Facebook adalah message(pesan), chat(obrolan) dan sebagainya.

5. Zero Time Feedback

Facebook secara langsung dapat menyampaikan umpan balik (feedback) atas komoditas mengenai saran dan kritik.

6. Konektivitas tinggi

Sebagai sarana berhubungan sama alam bisnis, maka bisnis tetap dijaga dengan baik selamanya.

7. Low Budget, High Impact

Facebook merupakan salah satu media bisnis gratis, sehingga akan dapat menurunkan biaya yang tidak perlu.

\section{New Wave Marketing}

(Lasmadiarta, 2011) mengatakan bahwa kini dunia pemasaran telah beralih dan menuju masa New Wave Marketing (gelombang baru pemasaran) yang mana Facebook adalah satu diantara pemicu utamanya.

Analisis SOSTAC 
Situation analysis diawali dengan mengidentifikasi posisi perusahaan dalam pemasaran digital saat ini. Perusahaan telah melaksanakan pemasaran digital selama enam bulan setelah bertahuntahun perusahaan melakukan promosi dengan personal selling dan direct marketing. Selanjutnya dilakukan analisis SWOT terhadap digital marketing yang dilakukan oleh perusahaan adalah :

\begin{tabular}{|l|l|}
\hline Strength & $\begin{array}{l}\text { menjangkau calon konsumen lebih banyak, } \\
\text { biaya pemasaran lebih rendah }\end{array}$ \\
\hline Weakness & $\begin{array}{l}\text { gambar produk terkadang tidak mencerminkan } \\
\text { kualitas sebenarnya karena resolusi layar } \\
\text { masing-masing gadget berbeda, konsumen } \\
\text { tidak bisa mengukur tekstur produk, adanya } \\
\text { ongkos kirim }\end{array}$ \\
\hline Opportunity & $\begin{array}{l}\text { Belum banyak perusahaan kompetitor yang } \\
\text { bergerak dibidang pengolahan dan } \\
\text { perdagangan produk pertanian yang go online, } \\
\text { ketersediaan berbagai jenis marketplace } \\
\text { (general dan spesifik) }\end{array}$ \\
\hline Threat & $\begin{array}{l}\text { Banyaknya penipuan yang terjadi pada bisnis } \\
\text { online, kesadaran kompetitor untuk } \\
\text { melaksanakan pemasaran digital, fenomena } \\
\text { gaptek (gagap teknologi) bagi sejumlah } \\
\text { konsumen yang kemudian memiliki } \\
\text { kecenderungan untuk bertransaksi offline }\end{array}$ \\
\hline
\end{tabular}

Variable politik dan ekonomi tidak berpengaruh pada pemasaran produk. Sementara variabel sosial dan teknologi mempengaruhi cara pemasaran produk produk. Dengan semakin berkembangnya teknologi, kehidupan sosial mengalami pergeseran gaya hidup. Semua orang memiliki gawai dan akses terhadap internet. Hal ini membuat perubahan pola belanja online dalam hal apapun. Mobilitas tinggi dan penawaran yang menarik juga mendukung seseorang untuk memilih berbelanja online.

Tujuan perusahaan dalam kacamata pemasaran jangka pendek adalah penjualan. Sementara tujuan jangka panjang yang ingin diraih adalah kepuasan pelanggan dan loyalitas pelanggan.

\section{$-\quad$ Strategy}

Berdasarkan analisis situasi yang dilakukan dan dengan mempertimbangkan tujuan perusahaan, maka perusahaan akan melaksanakan blended marketing sistem, yakni dengan pemasaran online dan offline. Pemasaran offline dilakukan dengan metode yang telah dilaksanakan sebelumnya, yakni personal selling dan direct marketing. Pemasaran online dilaksanakan melalui marketplace dan media sosial. Kombinasi antara marketplace dan media sosial dapat meningkatkan keputusan pembelian konsumen (Kusdiartini \& Anugraheni, 2018).

- $\quad$ Tactics 
Pemasaran online akan dilaksanakan melalui marketplace agromaret. Perusahaan mempersiapkan materi iklan yang baik berupa

Gambar produk yang nyata dan memperlihatkan detail produk.

Keterangan spesifikasi produk yang rinci

Gambar aset perusahaan dan kegiatan operasional perusahaan

Testimoni yang dikemas dengan meyakinkan

Penawaran menarik berupa diskon atau potongan harga dengan minimum pembelian

Kalimat persuasi atau dalam istilah digital marketing dikenal dengan copywriting

Kontak perusahaan yang dapat dihubungi dan fast response

Untuk mendukung marketplace, perusahaan dapat menggunakan fitur grup dalam media sosial facebook. Tercatat sebanyak 40 grup perdagangan produk peternakan dengan keyword susu yang ditemukan di facebook. Grup tersebut memiliki rentang jumlah anggota mulai dari ratusan hingga puluhan ribu orang.

(Lasmadiarta, 2011) menyebutkan bahwa hal terpenting dalam menjalankan penawaran adalah trust (kepercayaan), dengan media Facebook seseorang bisa menciptakan kepercayaan dengan cara membagikan informasi-informasi diantaranya:

- $\quad$ Sediakan informasi terkait profil sebanyak-banyaknya (dengan batasan tidak mengganggu privasi)

- $\quad$ Sediakan kontak dan alamat yang available dan fast response

- $\quad$ Sediakan nama-nama perusahaan rekanan (jika ada)

- Ikuti halaman public figure atau influencer

- $\quad$ bagikan sesuatu yang memiliki manfaat bagi pembaca

- $\quad$ Tampilkan gambar presentasi yang membuat calon pelanggan yakin

Pada tahap actions, maka semua taktik akan diterapkan. Pada waktu yang sama, dilaksanakan tahap control. Tahapan control dilaksanakan dengan tujuan memastikan apa yang terjadi dilapangan telah sesuai dengan rencana. Apabila terjadi perubahan, maka akan dilakukan evaluasi.

\section{KESIMPULAN DAN SARAN}

Berdasarkan analisis 4P, STP, SOSTACS yang telah dilaksanakan dapat disimpulkan bahwa posisi perusahaan adalah pemula dalam pemasaran digital. Meski demikian melalui pemasaran offline yang dilakukan perusahaan telah memiliki ratusan pelanggan loyal. Sehingga strategi pemasaran yang dilakukan adalah dengan mengkombinasikan pemasaran online dan offline. 
Dalam pemasaran digital, Perusahaan dapat menggunakan media sosial dan marketplace. Marketplace agromart difokuskan untuk memberi informasi yang lengkap terkait produk dan promosi yang massif untuk mendorong transaksi penjualan. Sementara media sosial facebook lebih difokuskan untuk membangun relasi dengan pelanggan dan kedekatan personal guna meningkatkan penjualan.

\section{Saran}

Saran yang dibagikan buat peneliti selanjutnya adalah dengan memakai lebih banyak alat analisis. Dengan semakin banyak alat analisis yang digunakan maka semakin tajam dan tepat pula analisis yang diperoleh.

\section{DAFTAR PUSTAKA}

Apriadi, D., \& Saputra, A. Y. (2017). E - Commerce Berbasis M arketplace Dalam Upaya Mempersingkat. Rekayasa Sistem Dan Teknologi Informasi, 1(2), 131-136.

Berita Terkini Ekonomi dan Bisnis Indonesia - Katadata. (n.d.).

Chaffey, D. Chadwick, F. Johnston, K. (2009). Internet Marketing: Strategy, Implementation, and Practice. Prentice Hall.

Chaffey, D \& Smith, P. (2008). E-marketing : Excellence. Butterworth-Heinemann.

Dharmmesta, Basu S,. Handoko, H. (2011). Manajemen Pemasaran-Analisis Perilaku Konsumen. In Basu Swastha. BPFE.

Febriyantoro, M. T., \& Arisandi, D. (2018). Debby Arisandi Halaman 61 dari 76 JMD. Jurnal Manajemen Dewantara, $1(2)$, 61-76. http://ejournal.stiedewantara.ac.id/index.php/JMD/issue/view/32

Finansialku. (n.d.).

Handoko, K. F. (2017). PENGARUH DESAIN VISUAL KEMASAN , KUALITAS INFORMASI , SERUNDENG MR. GORA SECARA ONLINE. Jurnal Manajemen Dan Start Up Bisnis, 2.

Kotler, Philip,. Keller, K. L. (2016). Marketing Management (15th ed.). Pearson Prentice.

Kusdiartini, V., \& Anugraheni, D. T. (2018). Preferensi konsumen terhadap media sosial dalam mencari dan membeli produk secara online. Ekonomi Dan Bisnis, 21(September), 8-17.

Lasmadiarta, M. (2011). Extreme Facebook Marketing for Giant Profits. Elex Media Komputindo.

Mokhtar, N. F. (2015). Internet Marketing Adoption by Small Business Enterprises in Malaysia. International Journal of Business and Social Science, 6(1), 59-65. 
Muttaqin, Z. (2012). Facebook Marketing Dalam Komunikasi Pemasaran Modern. Teknologi, 1(2), 103-109. https://doi.org/10.26594/teknologi.v1i2.63

Sarastuti, D. (2017). Strategi Komunikasi Pemasaran Online Produk Busana Muslim Queenova. Visi Komunikasi, 16(01), 71-90. www.queenova.com,

Utami, H. N., \& Firdaus, I. F. (2018). Pengaruh Bauran Pemasaran Terhadap Perilaku Online Shopping: Perspektif Pengaruh Bauran Pemasaran Terhadap Perilaku Online Shopping: Perspektif Pemasaran Agribisnis. Jurnal Ecodemica, 2(July).

Wardhana, A. (2015). Strategi Digital Marketing dan Implikasinya Pada Keunggulan Bersaing 